\title{
CZARDASZ I GULASZ - OBRAZY WĘGIERSKIEJ „INNOŚCI” W TWÓRCZOŚCI KRZYSZTOFA VARGI
}

\author{
AgNiEsZKa CZYŻAK ${ }^{1}$ \\ (Uniwersytet im. Adama Mickiewicza w Poznaniu)
}

Słowa kluczowe: inność, imagologia, pamięć, tradycja

Key words: otherness, imagology, memory, tradition

\begin{abstract}
Abstrakt: Agnieszka Czyżak, CZARDASZ I GULASZ - OBRAZY WĘGIERSKIEJ „INNOŚCI” W TWÓRCZOŚCI KRZYSZTOFA VARGI. „PORÓWNANIA” 20, 2017. T. XX, S. 87-96. ISSN 1733-165X. Artykuł zawiera interpretację dwóch utworów Krzysztofa Vargi, Gulaszu z turula (2007) oraz Czardasza z mangalica (2014). Teksty te - o zarazem autobiograficznym i reportażowym charakterze - stanowią rozpoznanie współczesnej świadomości zbiorowej zarówno Węgrów, jak i Polaków. Imagologia, jako fakt kulturowy oraz metodologia służąca badaniu obrazów i idei przybierających postać mitów, wzorców i motywów, okazuje się niezwykle przydatnym narzędziem w obszarze studiów kulturowych, szczególnie w nurcie badań postkolonialnych (postzależnościowych) oraz komparatystycznych.
\end{abstract}

\begin{abstract}
Agnieszka Czyżak, CZARDAS AND GOULASH - IMAGES OF THE HUNGARIAN “OTHERNESS" IN KRZYSZTOF VARGA'S OUTPUT. “PORÓWNANIA" 20, 2017. Vol. XX,P. 87-96. ISSN 1733-165X. The article contains interpretations of two compositions written by Krzysztof Varga, Gulasz z turula (2007) and Czardasz z mangalica (2014). Those works - with their character bordering on autobiography and reportage - constitute a recognition of the contemporary condition of collective consciousness, especially in Hungary, but also in Poland. Imagology as a cultural fact and the methodology of investigating images and ideas assuming the form of myths, patterns or motifs turns out to be a very useful for cultural (postcolonial and comparative) studies.
\end{abstract}

Funkcjonujące w ramach kultur narodowych wspólnotowe idee, wyobrażenia, mity czy toposy warunkują procesy poznawcze, wpływają na wytwarzanie obrazów rzeczywistości, wyznaczają strategie doboru i eliminacji określonych składników tradycji - zarówno w perspektywie jednostkowej, jak i zbiorowej. W twórczości Krzysztofa Vargi węgierska „inność” musi zostać ujęta w cudzysłów. Polski pisarz,

1 E-mail: agaczyz@amu.edu.pl 
piszący w języku polskim, jest synem Węgra i Polki, świadomym swojej podwójnej kulturowej przynależności. Podwójna czy raczej rozdwojona tożsamość twórcy staje się w jego pisarstwie, także publicystycznym, podstawą szerzej zakrojonych rozpoznań - analizie poddane zostają związki z dwoma przestrzeniami i tradycjami wspólnotowymi. Jednocześnie wraz z upływem lat, w koincydencji z rozwojem cywilizacyjnym, przemianom podlega jednostkowa perspektywa oglądu zbiorowych doświadczeń oraz zakres wywiedzionej z ogólniejszych rozważań autoanalizy.

W eseistycznej książce Gulasz z turula z 2007 roku refleksje zamknięte zostały w konwencji powrotu do mitycznej i wciąż od nowa mityzowanej krainy dzieciństwa. Pierwsze zdanie utworu brzmi: „W dzieciństwie na Węgrzech najbardziej lubiłem zapach rozchodzący się z mieszkań około godziny trzynastej, kiedy nakrywano do stołu" (Varga 2007: 7). Obrazy wędrówki czy raczej włóczęgi po rodzinnym kraju ojca zamyka zapowiedź wizyty na cmentarzu: „Następnego dnia pojadę do Budapesztu i wybiorę się na długi spacer po cmentarzu Kerepesi oglądać jędrne pośladki i piersi wykute na wieczność w nagrobnych kamieniach" (Varga 2007: 184). Ten spacer w cieniu śmierci - jak zresztą sugerowała zawartość całego utworu - okaże się raczej wizytą flaneura niż zmaganiem wędrowca z ciężarem spraw ostatecznych.

W kolejnym utworze z serii ${ }^{2}$, czyli Czardaszu z mangalica z roku 2014, refleksje z podróży po Węgrzech nabierają zdecydowanie poważniejszych tonów. Narrator mówi wprost: „Chcę tylko powiedzieć, że jako pół Polak, a pół Węgier nosić muszę podwójne brzemię klęsk, brzemię porażek dwóch narodów, to naprawdę nie jest przyjemny ciężar" (Varga 2014a: 157). Obrazy odwiedzanych miejsc i przemierzanych przestrzeni służą dookreślaniu zbiorowej tożsamości (przede wszystkim węgierskiej, ale także polskiej) oraz odsłanianiu osobistych relacji narratora z prezentowaną ikonosferą. Do rangi niepodważalnego symbolu węgierskiej, nie tylko dwudziestowiecznej, ale i najbardziej współczesnej świadomości zbiorowej urasta Pomnik Trianoński na placu Wolności w Budapeszcie (traktowany jako memento układu pokojowego z 1920 roku, w wyniku którego dwie trzecie terytorium Węgier i co trzeciego Węgra wcielono do sąsiednich państw ${ }^{3}$ ) - tym samym materialne upamiętnienie klęski sprzed niemal wieku pozostaje punktem odniesienia dla wytwa-

2 W obręb serii można włączyć, przy pewnych zastrzeżeniach - powieść Bildungsroman z 1996 roku, poświęconą relacjom synowsko-ojcowskim i procesom inicjacyjnym. Ostatnią książką z "cyklu węgierskiego" jest Langosz w jurcie - utwór wydany w roku 2016, określony przez autora jako „domknięcie trylogii”. Opowieść o węgierskich pograniczach otwiera scena śmierci ojca, wyznaczająca bardziej melancholijną perspektywę oglądu przeszłości. Rola proustowskiej magdalenki przypadła ziemniaczanej zapiekance z kiełbasą i boczkiem, potrawie popularnej na terenach zamieszkałych przez Węgrów, często przyrządzanej przez ojca narratora (Varga 2016).

3 Polska również została „upamiętniona” na pomniku jako jeden z grabieżców terenów z powodu kilku wiosek w okręgu Orawy i Spiszu, jednak - jak przekonuje węgierki historyk János Tischler - „Polska pozostawała jedynym państwem w bezpośrednim lub pośrednim sąsiedztwie Węgier, wobec którego nie żywiono roszczeń terytorialnych. Wręcz przeciwnie, Węgry kilkakrotnie szukały oparcia i sojusznika w Polsce dla swoich dążeń wyzwoleńczych, zresztą podobnie postępowali Polacy wobec Węgrów" (Tischler 14). 
rzanej od owego momentu "nowej” mitologii narodowej, poddawanej w utworze szczegółowej analizie.

Jednak nie tylko namacalne, punktowo umieszczone $\mathrm{w}$ przestrzeni pamiątki przeszłości służą dookreślaniu zbiorowej tożsamości. Tytułowy czardasz i gulasz to stereotypowo powiązane z obrazem Węgier elementy kultury i życia codziennego. Ognisty taniec i zawiesista potrawa pozostają rozpoznawalnymi, symbolicznymi znakami węgierskości. W tytułach, którymi zostały opatrzone książki, ważniejszy jednak okazuje się drugi człon - tajemniczo brzmiące słowa turul i mangalica to nazwy mitycznego ptaka i lokalnej odmiany świni. Gdyby więc stworzyć analogicznie spreparowane tytuły wędrówek po Polsce, mogłyby one brzmieć: „bigos z orła” $\mathrm{i}$ „polonez z wieprzkiem”. Zamysł autora wydaje się zatem przejrzysty - już na początku pisarz sugeruje jednoczesne nawiązywanie do imagologicznej tradycji węgierskiej kultury i jej naruszanie, zapowiada ironiczny namysł nad sposobami jej wytwarzania i prowokacyjne rozbijanie jej spójności.

Relacje z włóczęgi po miastach i miasteczkach, po stolicy i prowincji Węgier odsłaniają inność przemierzanej przestrzeni zarówno poprzez wskazywanie na ślady przeszłości, jak i przez przywoływanie elementów życia codziennego mieszkańców. Nie bez znaczenia okazuje się też (nad)używanie węgierskich nazw, tytułów i określeń w ich rozpoznawalnym dla każdego Europejczyka, jednak z reguły trudnym do przyswojenia kształcie. Książki obfitują w niezliczone opisy węgierskich miejscowości, placów, w ekfrazy pomników i dzieł plastycznych, analizy tekstów kultury wysokiej oraz rozważania na temat popularnych piosenek i filmów. Węgierskość pisarz tłumaczy zatem przede wszystkim za pomocą interpretacji wytworów węgierskiej kultury, znaków tradycji i wywiedzionych z niej elementów teraźniejszości.

Jednocześnie Varga nie unika kontrowersyjnych diagnoz współczesnego życia społecznego, próbuje dotrzeć do sedna odmienności Węgrów wśród innych narodów Europy, zrozumieć istotę ich "osobności”. Tym samym jego teksty zdają się stanowić świadomie tworzony "materiał źródłowy” dla badań imagologicznych. Lidia Wiśniewska w rozprawie Stoffgeschichte, imagologia i konstruktywistyczne uprawomocnienia komparatystyki podkreślając, iż rozpoznania imagologii aktualizują perspektywę zewnętrzną wobec „literackości” i domagają się uwzględnienia szerokiego społecznego i historycznego kontekstu - co oznacza także koncentrowanie się na poznawczej stronie ludzkiego istnienia - stwierdzała:

choć człowiek zdolny jest percypować rzeczywistość tylko cząstkowo, jego częściowe reprezentacje zmierzają do zawarowania sobie statusu całościowych, co wraz ze skłonnością do wartościowania właściwą jego sądom, prowadzić może do generowania prze(d) sądów (Wiśniewska 242).

Varga, konstruując świat przedstawiony z okruchów własnych doświadczeń, zmierza do stworzenia zindywidualizowanych, a jednak wykraczających poza 
przeżycie osobiste obrazów fenomenu zbiorowej tożsamości Węgrów. W jego pozornie "całościowym” i wartościującym ujęciu brak jednak - co trzeba wyraźnie podkreślić - dążenia do obiektywizacji procesu poznawczego.

Polski pisarz, wędrując po na wpół własnym terenie, nie może pozbyć się poczucia odrealnienia świata. We wstępie do zbioru Znikająca Europa, opatrzonym tytułem O mówiących ruinach, przesuniętych granicach $i$ niewidzialnych miastach, Katharina Raabe i Monika Sznajderman zauważają:

Utracone, opuszczone, zdradzone przez historię i przyrodę przestrzenie mają dziwny, nierzeczywisty urok [...]. Gdy rzeczy i miejsca tracą kontekst, który nadawał im funkcję, można w nich czytać. Bezużyteczne, w pewnym sensie wyzwolone, zyskują osobliwą aurę. Nie tylko my widzimy je na nowo, również one kierują na nas zdziwiony wzrok i próbują zadać nam pytanie (Raabe, Sznajderman 6).

W prozie Vargi te „inne”, poddane lekturze i interpretacji przestrzenie nie stają się tylko przedmiotem doświadczenia estetycznego, ich oswajanie pozwala dookreślać kulturową tożsamość zarówno mieszkańców, jak i połączonego z nimi więzami krwi wędrowca.

We wczesnym utworze Vargi, zatytułowanym Bildungsroman, wydanym po raz pierwszy w 1996 roku padają znaczące słowa potwierdzające autoanalityczny i zarazem autoironiczny - charakter tekstu: „Twoja pamięć jest wybiórcza Kristóf, wybiórcza i obsesyjna. Beatyfikujesz miejsca zwyczajne" (Varga 2014b: 224). Selekcja doświadczeń nie służy więc obiektywizacji przekazu, lecz pozostaje organicznie powiązana $z$ jednostkowym procesem poszukiwania tożsamości. Ta „powieść o dojrzewaniu" zawiera zarazem świadome wyznania autotematyczne: „Twoja głowa Kristóf, co się w niej dzieje, jakieś zupełnie nieprawdopodobne historie, wspomnienia mieszają się z urojeniami, powstają konfabulacje, miasta nachodzą na siebie i rodzą się molochy, miasta trupów, gigantyczne nekropolie" (Varga 2014b: 225). Przed zarzutem „niesprawiedliwego osądu” chroni zatem owe „konfabulacje” ich jawnie kreacyjny, fantasmagoryczny charakter.

Przemierzanie przestrzeni wywołuje ruch myśli. Aleida Assmann, pisząc o przestrzeniach pamięci, przekonywała, iż biograficznej i kulturowej pamięci nie da się w prosty sposób „składować w miejscach”. Miejsca pojmować należy raczej jako specyficzne katalizatory pamięci, albowiem:

mogą wywoływać i wspierać procesy pamiętania tylko w powiązaniu z innymi mediami pamięci. Tam, gdzie zostały zablokowane wszelkie możliwości przekazu, powstają miejsca widma, które stają się areną swobodnych gier wyobraźni lub powrotu wypartych znaczeń (Assmann 114).

Przestrzeń Węgier oglądana oczami częściowo tylko związanego z nią autora, "filtrowana" przez jego świadomość, odkształcana przez pamięć oraz aktualne osą- 
dy przeszłości i teraźniejszości staje się krainą nieuleczalnej depresji, wylęgarnią samobójców, krainą przesyconą smutkiem i melancholią. Narrator stwierdza z ironią:

Ofiarą węgierskiego smutku i niechęci do życia padają przede wszystkim warzywa synonim świeżości, zdrowia i lekkości. Warzywo trzeba zabić, upolować jak zwierzę, wszystko, co żywe, zawierające witaminy, należy z tego życia i zdrowia wypatroszyć, utopić w occie lub udusić w zasmażce ze smalcu i mąki (Varga 2007: 22).

Spowita smutkiem i przesiąknięta pamięcią o niezliczonych klęskach kraina trwa w nadziei na odmianę wspólnotowego losu, na poprawę zbiorowej kondycji, a jej mieszkańcy trawią czas na analizowaniu przyczyn nieszczęścia i porządkowaniu patriotycznego imaginarium.

W obronie przed globalizacją szczególna rola przypada właśnie narodowym potrawom. Przemysław Czapliński w Poruszonej mapie tak przedstawił obraz Węgrów wywiedziony z twórczości Vargi: „Po upadku komunizmu nie stracili apetytu i uczestniczą w narodowej orgii seksualno-kulinarnej. W rzeczywistości jednak to nie apetyt popycha do stołu, lecz pochłanianie potraw stymuluje apetyt" (Czapliński 292). Traktowanie kuchni jako specjalnego kodu, sekretnego języka porozumienia Varga ukazuje z perspektywy postkolonialnego przewodnika, tropiącego niepoznawalną, egzotyczną inność (Czapliński 292-293), jednocześnie czując się jej depozytariuszem, w dodatku rozpoznającym - dzięki rozdwojonej tożsamości - sedno podobieństw węgierskiej i polskiej kultury ${ }^{4}$. Tym samym lokalność, podniesiona do rangi celebrowanego sacrum, staje się nakazaną normą codziennych praktyk.

Varga w swoich tekstach stosuje najczęściej strategię prowokacji - nadmiernie wyostrza (i tak kontrowersyjne) tezy, drażni jednoznacznością stawianych diagnoz, rozdaje ciosy na prawo i lewo, za wszelką cenę usiłuje wytrącać czytelnika nie tylko ze stereotypowych przeświadczeń, ale i z dobrego samopoczucia. Węgierskim odbiorcom omawianych tekstów, szczególnie tym przywiązanym do narodowych symboli, trudno jest z pewnością przyjmować sarkastyczną wiwisekcję przeszłości i teraźniejszości wspólnoty - podobnie jak i wielu polskim odbiorcom mogą sprawiać kłopot publicystyczne diagnozy pisarza, skupiające się na piętnowaniu zbiorowych przywar. Znane powiedzenie „Polak, Węgier, dwa bratanki i do szabli, i do szklanki" zyskuje w prozie Vargi także inny wymiar - to braterstwo w szczególnej predyspozycji obu narodów do pielęgnowania pamięci o heroicznie znoszonych klęskach, bohatersko przegrywanych zrywach narodowych. Narrator wspomina o istnieniu przedziwnej wielkiej księgi, zatytułowanej Polska $i$ Wegry, wydanej w 1936

4 Czapliński podobieństwo dostrzega w przyjętym modelu nowoczesności, od którego wymaga się zachowania swojskiej kultury w stanie niezmienionym: „Oba społeczeństwa próbują tego dokonać poprzez neurotyczne powtarzanie formy lokalnej, którą wykorzystują jako samodzielną podnietę do działania i zarazem jako towar w globalizującym się świecie" (Czapliński 295). 
roku - złożonej z czterystu pięćdziesięciu stron dużego formatu małym drukiem. Bogato ilustrowane dzieło otwierają portrety prezydenta Mościckiego, marszałka Piłsudskiego i regenta Horthy'ego. Narrator stwierdza z pełną sarkazmu emfazą:

Jest to iście mityczna księga, która mogłaby się pojawić w jakimś opowiadaniu Schulza, Borgesa czy Kiša. Księga, która zawiera WSZYSTKO [...], jest tutaj i realizm, i baśń, i proza, i poezja, i mania, i depresja, i skrupulatność podawania dokładnych danych statystycznych ze sprzedaży zboża, ziemniaków i buraków, i szalona eseistyka zbudowana nie na faktach, lecz na emocjach (Varga 2014a: 185).

Przedziwne połączenie mitologii z rocznikiem statystycznym określił Varga „nieświadomym dziełem postmodernistycznym” - ta trudno dostępna księga, która mogłaby stać się "polsko-węgierską Biblią”, pozostaje dziś ciekawostką, lekturą dla domorosłych "maniakalnych badaczy” wzajemnych relacji obu narodów. Jednak jej zawartość potwierdza istnienie trwałych i w istocie niezmiennych zasad budowania narodowej tożsamości na wybiórczo kompletowanych i dowolnie interpretowanych obrazach przeszłości.

Obraz Węgier, ukazywany jednostronnie i bez dbałości o szczegółowe rozpoznanie tematu, pozwala pisarzowi na kreślenie wizji zagrożeń związanych ze współczesnymi dążeniami do konsolidowania zbiorowości wedle dziewiętnastowiecznych reguł. Zdaniem Vargi mitologia wywiedziona z historii i wsparta na traktowanej służebnie interpretacji minionych faktów znów zaczyna służyć projektowaniu kompensacyjnych ideologii. Budowanie zrębów tożsamości zbiorowej, tworzenie kolejnych odsłon kreowanego odgórnie, w zamyśle zaś obowiązującego powszechnie obrazu świata łączy się z kolei najczęściej z wykorzystywaniem sztafażu narodowej mitologii ${ }^{5}$. Niezliczona ilość pomników służyć ma nie tyle upamiętnianiu, co wytwarzaniu pamięci. Narrator wspomina na przykład mało znany, postawiony na uboczu węgierski Pomnik Naszej Smutnej Historii, który uznaje za jedną z „najbardziej przejmujących rzeźb martyrologicznych”. Dodaje jednak: „Skromna rzecz, inna zupełnie od stojącego kilkadziesiąt metrów dalej honweda z pierwszej wojny, o wiele większego, na wysokim postumencie ma się rozumieć, dzierżącego w jednej ręce wzniesiony sztandar, a w drugiej karabin" (Varga 2014a: 191). Pojedynczy pomnik cywilnych ofiar wojny ustępuje pola niezliczonym pomnikom militarnym - także tym pojawiającym się od stosunkowo niedawna, które oddają hołd żołnierzom walczącym w czasie II wojny światowej w sojuszniczej armii III Rzeszy.

Monumenty, obeliski, rzeźby wszechobecne w publicznej przestrzeni służą podtrzymywaniu akceptowanej wizji dziejów. Eelco Runia w eseju Obecność wska-

5 Narrator Czardasza z mangalica podkreśla: „premier Orban uwielbia używać wojennej retoryki, nieustannie toczy wojny, zwycięża w kolejnych bitwach, staje na czele nowej rewolucji [...], odnosi się wrażenie, że oto nastała jakaś współczesna wersja roku 1848" (Varga 2014a: 161). 
zywał na istotę współczesnych koncepcji uobecniania przeszłości: „Pomniki, tak jak inne dzieła sztuki są idiosynkratycznymi związkami metonimicznej denotacji i metaforycznej konotacji: mówią coś (konotacja) o czymś, co reprezentują (denotacja)" (Runia 103). Jednocześnie Runia zauważał w tym samym miejscu:

Współczesne pomniki w większości można określić jako metonimiczne: denotacje górują nad konotacjami [...]. We współczesnym pomniku chodzi głównie o to, żeby dokonać metonimicznej transpozycji "treści" - co czynią betonowe kolumny w pomniku Holocaustu w Berlinie - z jednego miejsca w drugie. Treść tak wypełnia miejsce, że nie można $\mathrm{z}$ niego uciec (Runia 103).

Tym samym pomniki będące "przekształceniem miejsca w czas” służą kreowaniu aktualnie dogodnej wizji przeszłości. Runia podkreśla, iż współczesne monumenty, choć przedstawiają (wyrażają) tu i teraz wydarzenia z przeszłości, to w istocie prawie wcale ich nie reprezentują.

Pomnik w zbiorowej świadomości niejednokrotnie przestaje nawet być obiektem stworzonym $\mathrm{w}$ konkretnych warunkach i zgodnie $\mathrm{z}$ wyraźnie określonym zapotrzebowaniem, a staje się pozornym, zastępczym „reliktem” dziejów. Takim "dowodem" przeszłości, a w istocie jej dogodną interpretacją okazują się też dzieła malarskie. Wielka panorama (piętnaście metrów wysokości i sto dwadzieścia metrów długości) autorstwa Fesztyego, powstała pod koniec XIX wieku, przedstawia akt Zajęcia Ojczyzny. Narrator przeprowadza ekfrastyczny opis dzieła z sarkazmem wymierzonym w obowiązujące interpretacje:

Arpad na wzgórzu nie patrzy w przyszłość, nie rozmyśla nad węgierskim losem, on obserwuje z zadowoleniem masakrę, którą urządzają jego wojownicy. Robi to, co umie najlepiej - rządzi, najeżdża, morduje [...]. Ta nizina, na którą wkroczył, to przystanek na jego zbójeckiej drodze. Niewykluczone, że nawet mu się tu podoba, ale jest przecież nomadą, tak jak jego siedem zjednoczonych plemion (Varga 2007: 178).

W ujęciu Vargi prowadzący osiadłe, rolnicze życie Słowianie byli w jednoznaczny sposób ofiarami Madziarów. W Czardaszu z mangalica jeszcze dosadniej wyrażony został sprzeciw wobec nadużyć w tworzeniu narodowych mitologii i po raz kolejny pojawiła się próba odsłonięcia niepokojącej trwałości raz wytworzonych przekłamań. Pisarz przypomniał, jak przedwojenny węgierski minister obrony narodowej, określony przez niego (na wyrost) jako zaprzysięgły faszysta, podsumowywał historię narodu: „Wraz z duchem chrześcijańskim od tysiąca lat utrzymaliśmy zdobytą mieczem Ojczyznę" (Varga 2014a: 186) ${ }^{6}$.

6 W dalszej części przywoływanego przez Vargę tekstu pojawiła się też mocno uproszczona, silnie nacechowana ideologicznie diagnoza wspólnoty polskich i węgierskich dziejów: „Potęga wiary 
Dokładniejsza analiza doprowadziła pisarza do wniosku, iż mitologizowane "Zajęcie Ojczyzny" okazało się eufemizmem przesłaniającym brutalny podbój. Jeszcze większym nadużyciem wydała mu się sugestia, iż wojownicy Arpada przemocą zajmujący Panonię w roku 896 i wyrzynający jej ówczesnych mieszkańców byli niosącymi cywilizacyjną zmianę kolonizatorami, oraz to, że zmiatający z powierzchni ziemi słowiańską państwowość Madziarzy „walczyli z poganami”, skoro sami trwali wówczas w pogaństwie. Namysł autora Czardasza z mangalica wzbudziła także dzisiejsza popularność legendarnej, utrwalonej w tekstach kultury opowieści o pokrewieństwie Hunów i Madziarów, pochodzących jakoby od dwóch braci, Hunora i Magora ${ }^{7}$.

Apologia lokalności, osobności, wyrazistej odmienności może przekształcać się w kreowanie wyjątkowości narodowego losu także przy użyciu wcześniej odrzucanych przekazów historycznych, mitów i legend. Varga przekonuje nadto, przerysowując swoim zwyczajem zaobserwowane zjawisko, iż „węgierskość jest coraz bardziej mitologiczna, idzie w poprzek zupełnie się laicyzującej Europy, pogrążając się w swojej odrębności, może nawet wbrew tej Europie sakralizując się na pogański sposób” (Varga 2014a: 193-194). „Repoganizacja”, bliska podobnym ruchom w Skandynawii, służyć miałaby odbudowie i utrwaleniu "mitu o potędze”, o czasie chwalebnym. Pamięć przeszłości, budowanej od nowa z niekoherentnych fragmentów legend, mitów, zdarzeń historycznych, a nade wszystko ich dzisiejszych, preparowanych w określonym celu interpretacji ujawnia swój kompensacyjny charakter. Wielkie węgierskie, pogańskie odrodzenie prowadzić może (w krytycznym oglądzie Vargi) do wzmacniania odrębności nie tylko wobec Europy, ale i przeciw Europie.

Węgry (podobnie jak Polska) znajdują się w okresie przyspieszonych przemian kulturowych. W obu krajach na znaczeniu zyskują zwolennicy świadomego kreowania własnej inności (wyższości) w aktach reinterpretacji obrazów historii - polski pisarz, "pól-Węgier" zrazu przyglądał się temu procesowi z dystansem, obecnie odmawia uczestnictwa w tych i podobnych działaniach, kierowany obawą o możliwe następstwa dokonywanych dziś wyborów. Ponieważ wyznaczył sobie zadanie piętnowania niepokojących przejawów zamykania się na inność, odmienność, wielorakość, nieustannie stara się tropić najrozmaitsze zafałszowania zbiorowej

chrześcijańskiej dała obu narodom siłę moralną, niezmożoną cierpliwość do znoszenia największych nawet ciosów" (Varga 2014a: 186).

7 Bracia, polując na mitycznego, cudownego jelenia, zamiast niego złapali dwie przepiękne panny, z którymi spłodzili Hunów i Madziarów, czyli - jak bezpardonowo stwierdza Varga - "paskudne, barbarzyńskie utrapienie średniowiecznej Europy". Narrator tak dalej komentuje legendarną opowieść, przekraczając po raz kolejny granice stosowności i odrzucając postawę zobiektywizowanego dystansu: „Gdyby najeżdżani, rabowani, mordowani i gwałceni Europejczycy tamtych wczesnośredniowiecznych czasów wiedzieli, że wszystko to dlatego, że jakimś dwóm idiotom uciekł na polowaniu jeleń, to by sami w ofierze złożyli tysiąc jeleni, byleby wymodlić zniknięcie tych dzikusów" (Varga 2014a: 193). 
świadomości. Nie uznaje mocy sprawczej zrodzonych na gruncie ideologicznym mitologii narodowej tożsamości, podobnie jak nie godzi się na to, by stawały się bezkrytycznie przyjmowanym wzorcem wspólnotowych działań. Wyznaczanie członkom wspólnoty nieprzekraczalnych granic w sferze codziennego funkcjonowania i dozwolonej ekspresji, których tylko bezwarunkowa akceptacja potwierdza przynależność do zbiorowości, a także narzucanie obowiązujących stereotypów określających narodową tożsamość prowadzą ostatecznie do ksenofobii i uniemożliwiają zarówno otwarcie na wszelkie przejawy inności, jak i włączenie w nurt cywilizacyjnych przemian.

\section{BIBLIOGRAFIA}

Assmann, Aleida. „Przestrzenie pamięci. Formy i przemiany pamięci kulturowej”. Przeł. Piotr Przybyła. Pamięć zbiorowa i kulturowa. Wspótczesna perspektywa niemiecka. Red. M. Saryusz-Wolska. Kraków: Universitas, 2009. S. 109-123.

Czapliński, Przemysław. „Wątpliwe południe”. Poruszona mapa. Wyobraźnia geograficzno-kulturowa polskiej literatury przełomu XX i XXI wieku. Kraków: Wydawnictwo Literackie, 2016. S. 267-318.

Raabe Katharina, Sznajderman Monika. „O mówiących ruinach, przesuniętych granicach i niewidzialnych miastach". Znikajaca Europa. Red. K. Raabe, M. Sznajderman. Wołowiec: Wydawnictwo Czarne, 2015. S. 5-7.

Runia, Eelco. „Obecność”. Przeł. Elżbieta Wilczyńska. Teoria wiedzy o przeszłości na tle wspótczesnej humanistyki. Red. E. Domańska. Poznań: Wydawnictwo Poznańskie, 2010. S. 75-124.

Tischler, János. I do szabli... Polska i Wegry. Punkty zwrotne dziejach obu narodów w latach 1956 oraz 19801981. Przeł. Botond Héjj. Warszawa: Ludowa Spółdzielnia Wydawnicza, 2001.

Varga, Krzysztof. Czardasz z mangalica. Wołowiec: Wydawnictwo Czarne, 2014a.

Varga, Krzysztof. 45 pomystów na powieść. Bildungsroman. Wołowiec: Wydawnictwo Czarne, 2014b.

Varga, Krzysztof. Gulasz z turula. Wołowiec: Wydawnictwo Czarne, 2007.

Varga, Krzysztof. Langosz w jurcie. Wołowiec: Wydawnictwo Czarne, 2016.

Wiśniewska, Lidia. „Stoffgesichte, imagologia i konstruktywistyczne uprawomocnienia komparatystyki". Wiek XIX. Rocznik Towarzystwa Literackiego im. A. Mickiewicza. XLVI (2011). S. 233-244. 